\title{
EVALUATING AND SELECTING OPTIONS FOR OIL REFIT PROGRAMS
}

\author{
R. Hoppe, W. Graves, and F.J. Salzano
}

February 1980

\section{DEPARTMENT OF ENERGY AND ENVIRONMENT}

BROOKHAVEN NATIONAL LABORATORY UPTON, NEW YORK 11973 


\section{DISCLAIMER}

This report was prepared as an account of work sponsored by an agency of the United States Government. Neither the United States Government nor any agency Thereof, nor any of their employees, makes any warranty, express or implied, or assumes any legal liability or responsibility for the accuracy, completeness, or usefulness of any information, apparatus, product, or process disclosed, or represents that its use would not infringe privately owned rights. Reference herein to any specific commercial product, process, or service by trade name, trademark, manufacturer, or otherwise does not necessarily constitute or imply its endorsement, recommendation, or favoring by the United States Government or any agency thereof. The views and opinions of authors expressed herein do not necessarily state or reflect those of the United States Government or any agency thereof. 


\section{DISCLAIMER}

Portions of this document may be illegible in electronic image products. Images are produced from the best available original document. 
BNL 51159

UC-95d

(Energy Conservation-Buildings and

Community Systems - TID-4500)

\title{
EVALUATING AND SELECTING OPTIONS FOR OIL REFIT PROGRAMS
}

\author{
R. Hoppe, W. Graves and F.J. Salzano
}

This book was prepared as an account of work sponsored by an agency of the United States Government. Neither the United States Government nor any agency thereof, nor any of their employees, makes any warraniv. express or imelied. or assumes any legal liability or responsibility tor the accuracy.

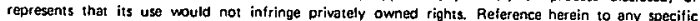
commercial product, process, or sarvice by trade name, trodemark, manufacturer, of otherwise, does not necesserily constitute or imply its endorsement, recommendation, or favoring by the Unitad States Government or any agency thereof. The views and opinions of authors expressed herein do not

February 1980

\author{
F.J. SALZANO, HEAD
}

ENERGY STORAGE AND CONVERSION DIVISION

ENERGY TECHNOLOGY PROGRAMS

DEPARTMENT OF ENERGY AND ENVIRONMENT

BROOKHAVEN NATIONAL LABORATORY

ASSOCIATED UNIVERSITIES, INC.

UNDER CONTRACT NO. DE-ACO2-76CH00016 WITH THE UNITED STATES DEPARTMENT OF ENERGY 


\section{DISCLAIMER}

This book was prepared as an account of work sponsored by an agency of the United Statos Govornmont. Noithor tho Unitod Statoo Covornmont nor any agonoy thoroof; nor any of their employees, makes any warranty, express or implied, or assumes any legal liability or responsibility for the accuracy, completeness, or usefulness of any intormation, apparatus, product, or process disclosed, or represents that its use would not infringe privately nuned rights Referen nẹe herẹin to any spesific sommercial prod. uct, process, or service by trade name, trademark, manufacturer, or otherwise, does not necessarily constitute or imply its endorsement, recommendation, or favoring by the United States Government or any agency thereof. The views and opinions of authors expressed herein do not necessarily state or reflect those of the United States Government or any agency thereof.

Printed in the United States of America

Available from

National Technical Information Service

U.S. Department of Commerce

5285 Port Royal Road

Springfield, VA 22161

Price: Printed Copy Microfiche $\$ 3.00$

S. 5 
Brookhaven National Laboratory (BNL) Oil Refit Program provides technical. support for the U.S. Department of Energy (DOE) Fuel Oil Conservation Marketing Demonstration Program implemented in several states (designed to accelerate the use of fuel saving devices and systems by homeowners). BNL assisted with the planning and implementation of the marketing and grants option phases for the New York State Pilot Marketing Demonstration Program and is monitoring the results. Additionally BNL planned, and is implementing, the Oil Refit Option Qualification Program involving procedures: for evaluating refit options for selection, field testing, and quantifying fuel savings for the purpose of qualifying additional options for use in the DOE state and other marketing programs. This report shows the BNL approach for the evaluation of options on a comparative basis and examines the potential for optimizing fuel savings by combining available single-choice refit options. Also shown are the estimated fuel savings for each option installed. 
I. $\quad$ INTRODUCTION $\ldots \ldots \ldots \ldots \ldots \ldots \ldots \ldots \ldots \ldots \ldots \ldots \ldots \ldots \ldots \ldots \ldots \ldots$

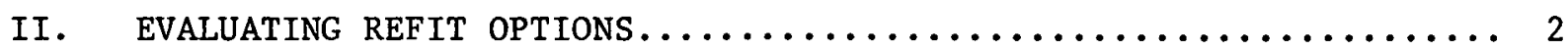

III. COMBINING SINGLE-CHOICE OPTIONS TO ACHIEVE

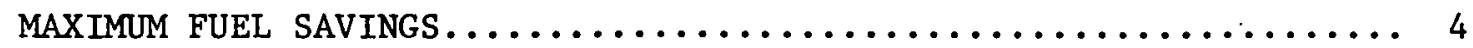

IV. QUANTIFYING FUEL SAVINGS IN REFITTED HOMES.............. 5 FIGURES :

Figure 1 - Refit Option Evaluation................... 7

Figure 2 - Refit Options......................... 10 
EVALUATING AND SELECTING OPTIONS

FOR OIL REFIT PROGRAMS

\section{INTRODUCTION}

The U.S. Department of Energy (DOE) has implemented a Fuel $0 i 1$ Conservation Marketing Demonstration Program in several states as a means to accelerate the installation of fuel saving devices in the home. Included as an essential part of this program are the following qualified options, selected on the basis of availability, acceptability, and proven fuel savings potential: flame retention head burner, automatic setback thermostat, replacement burnerboiler and furnace, and optimized firing rate. Since many other devices and systems are available and may be effective in reducing oil consumption, the DOE has charged the Brookhaven National Laboratory (BNL) with the task of designing and implementing a program to qualify additional options.

The BNL Oil Refit Option Qualification Program was approved for that purpose and is being implemented. It includes examining and evaluating other available options and installation in homes of a statistically significant number of each option selected. This major field demonstration will provide the necessary data to allow BNL to quantify fuel savings and identify servicerelated problems. The BNL program planning approach for evaluating and selecting options for the field demonstration has provided sufficient information to be of value to those involved in refit programs and is included in this report. Interim and final reports will be issued as the program progresses.

Even though proper home weatherization is not discussed in this report, it is recognized as necessary for fuel conservation. Weatherization relates to improving the efficiency of the structure and this report is concerned with the means by which the home heating unit efficiency can be improved by refit. Combining the options available in both areas is necessary to achieve maximum fuel savings in the home.

The following task areas are shown in brief detail only to demonstrate the scope and criteria for the BNL Oil Refit Option Qualification Program and should be of general interest.

A. List and Evaluate Refit Options

These shall be options which are currently being marketed for application to furnaces and boiler heating units and which are of most general interest.

B. Qualify Options for Use in the Field Demonstration

These shall be options selected by use of the evaluation procedures developed by BNL and will include single choice and combinations of options.

C. Select Field Demonstration Housing Sites and Homeowner Recipients for Refit Option Installations

These shall be housing sites of sufficient size to provide a selection of up to 300 homeowners to receive refit options installed at no cost to them. 
D. Implement Refit Option Installations in the Field

A single local fuel supply and service company will be selected to make the installations and provide the necessary fuel use data and service information necessary for the success of the program.

\section{E. Quantify Fuel Savings for Options Installed in the Field}

Other methods to quantify fuel savings from field-derived data will be evaluated and a method will be selected to provide information as accurate as possible.

\section{EVALUATING REFIT OPTIONS}

Refit devices and systems available to the public are numerous, diverse in function, cost, and benefit, and are invariably marketed as singip rhnire options. Selection of an option to suit a homeowner's needs can be difficult. In many cases a selection may not be appropriate because of the existing heating system, the living habits of the individual(s), constraints on investment capability, and a general lack of knowledge regarding the comparative benefits of refit options.

BNL has devised an evaluation procedure to aid in selecting options on a comparative basis and, in addition, has demonstrated that a proper combination of some single choice options, can achieve maximum fuel savings. This procedure requires grading the option in question with regard to categories of improvement to the existing system, with consideration for costs, fuel savings, additional annual service costs, etc.

The categories used as criteria for evaluating options in the BNL program include the following:

\section{A. Improvement of the Combustion Process and/or Heat Transfer}

Typically, an oil-fired forced hot wacer, steam, or forced warm air heating unit consists of two major components. The oil burner, which is designed to mix atomized fuel with air and ignite the mixture also introduces the resulting hot gases into the second major component, the boiler or furnace. Essentially the boiler or furnace provides a receptacle (combustion chamber) to receive the hot gases safely and distribute them through an integral heat exchanger which heats the water or air circulated around it. An improvement in this category introduces and/or provides more useful energy per unit of fuel consumed and reduces fruel consumption.

\section{B. Reduction in Off-Cycle Losses}

Depending on the heating unit, some of the stored heat In the buller or furnace is wasted when the burner is not operating. In addition, and depending on the proximity of the heating unit to the heated part of the home, some heated air can be lost through the burner and the barometric damper which is installed in the heating unit flue as required to control draft for proper venting of waste flue gases when the oil burner is operating. An improvement in this category also provides more useful energy for distribution in the home and can reduce fuel consumption. 
C. Waste Heat from Flue Gases and Other Sources Reclaimed and Recycled (e.g. Solar Systems)

Since no typical heating unit effectively utilizes all of the energy supplied to it, most of the unused heat is wasted up the chimney. It is desirable to reclaim and recycle some of the waste heat to provide more energy for distribution in the home and to reduce fuel consumption.

D. Reduction in Space Heat Demand

This is typically accomplished by reducing the controlled temperature in the home for extended periods at different levels of comfort. This can be: accomplished at no cost by manually operating thermostats, but an automatic control can provide more consistent savings. It is generally accepted that reducing the heat demand in a home will result in fuel savings.

\section{E. Provision of a New Heating Unit Component (s)}

Since all oil-fired heating units consist of two major components, the burner and the boiler or furnace, it would be desirable to select a refit. option which replaces one of the major components with a new one. This consideration could result in extending the usable life of an existing system.

\section{F. Additional Annual Service Costs}

Most existing agreements between homeowners and oil supply and service organizations consist of a service contract at a cost separate from the cost for fuel. Some refit options require annual service attention to assure efficient and safe operation, and the cost for this service will generally be an addition to the cost for the existing heating unit service contract. This should be a consideration when selecting options since it has a direct effect on net savings.

G. Installed Cost

Installed costs for options differ significantly and are affected by many variables including the purchasing power of the installer, their labor and overhead costs, inspection fees, the condition of the existing heating unit, and in some cases what the public is willing to pay. Ideally, the refit option installer should provide an itemized cost estimate, and the consumer should consider getting other bids for comparative purposes.

H. Annual Fue1 Savings

Fuel savings vary considerably with options and are difficult for an installer to quantify. It may" be impossible for him to guarantee savings. In the RNT, program, a methodology was'developed to quantify fuel savings from data as a result of a field demonstration which requires a statistically acceptable number of installations for each refit option selected. The fuel savings shown in this report are estimated or taken from BNL tests in the laboratory and will be supplemented with savings from the field demonstration as they become available.

Figures $1 \& 2$ in this report demonstrate the application of the above evaluation procedure. 


\section{COMBINING SINGLE-CHOICE OPTIONS TO ACHIEVE MAXIMUM FUEL SAVINGS}

The approach to combining single-choice options was developed by examining one of the most acceptable options used in existing refit programs. This was determined to be the flame retention head burner and it was found that most installations involved very little additional work when a burner was installed. As a result, optimized fuel savings probably are not achieved. The following is generally agreed to be the minimum work required for a burner installation and collectively can be considered as a single choice option, and will be referred to as the "optimized fine tune" option.

A. A flue gas analysis should be made for the existing system in order to justify recommending the burner option and the homeowner's investment. The test should be performed after an annual cleaning and where approprfale draft and burner adjustments were made. Generally, a combustion efficiency of $75 \%$ or less indicates that efficiency will be improved by the use of a tlame relention head burner if, indeed, the existing burner is not already a retention head design. In most cases, the retention head burner can, by design, reduce off-cycle heat losses by minimizing the free convective a1r flow through the burner when the burner is not operating. An efficiency test made in the field does not show this benefit and the flue gas analysis should be performed using a calibrated analyzer.

B. The condition of the combustion chamber and heat exchanger should be evaluated and repairs (or replacement) recommended for safe operation.

C. The combustion chamber and heat exchanger should be cleaned as required and all excess air openings to the combustion chamber should be sealed. Proper cleaning of heat exchanger surfaces is the most effective means for improving system performance and should include soot removal and scale buildup, particularly in fire tubes or similar passages.

D. The new burner should be installed with a matched end cone to allow for reducing the firing rate, and all excess air openings around the mounting flange and blast tube should be sealed. The installation shall be made in accordance with the manufacturer's instructions supplied with each burner.

E. Fuel suction line connections should be checked to assure an airtight installation. The burner should be operated and adjusted using the flue gas analyzer and proper draft adjustments should be made. Excessive diaft can result in excessive fuel consumption, whereas insufficient draft over the fire can result in excessive soot and scale buildup in heat exchanger gas passages.

F. A final check should be made for after-burning and all problems should be corrected immediately. After-burning occurs when raw fuel leaves the burner nozzle after the burner stops, igniting on hot surfaces and contributing to an accelerated degradation of heat transfer due to excessive soot accumulations on the heat exchanger surfaces. "A solenoid shutoff valve for installation in the fuel line is available to minimize this problem. 
G. Boilers should be insulated as required to minimize jacket losses.

When effectively combined, the "retention head burner" option and the work described above as the "optimized fine tune" option can result in greater fuel savings than can be achieved by simply installing the new burner.

Other options can be added to. reduce fuel consumption further. For example, in the case of a steel fire tube boiler where turbulators (baffles) are not in place, the installation of the "turbulator" option can improve heat transfer. In most cases, the collective benefits from the "retention head burner", "optimized fine tune" and the "turbulator" options justify the addition of the "reduced firing rate" option. This combined option package can achieve an estimated annual fuel savings of $25 \%$ and if these options are installed during a single work period, the cost in excess of the burner installation is estimated to be up to $\$ 100$. This example demonstrates the value of combining single-choice options for maximum fuel savings and encourages development of other combinations. It can further serve as a "work statement" for the installation of new improved burners.

Figures 1, 1-a etc. in this report list numerous single-choice options evaluated using the procedure described in Section II. Figure 2 in this report list single-choice and combination options selected and approved for use in the field demonstration for the BNL Refit Option Qualification Program.

\section{QUANTIFYING FUEL SAVINGS IN REFITTED HOMES}

BNL has chosen the following method to quantify fuel savings in refitted homes. A commercially available scientific information retrieval (SIR) data base was selected because it is widely available, flexible in size, requires minimal programing, and provides confidentiality. Inputs include fuel delivery data from the oil dealer who will implement home refit installations in the housing area selected for the field demonstration. Other inputs include daily maximum and minimum outside temperatures taken at the BNL site and characterization of the homes in terms of their heating load, occupancy, site orientation, heating unit efficiency, and other parameters. The BNL position at this point is that annual fuel savings cannot be quantified effectively by simply measuring fuel use change during a limited winter time period. Such information implies a trend, but the limited time procedure cannot be used to quantify annual savings.

The analysis of the field performance of options in homes requires a determination of the fuel savings in each refitted home by comparing fuel use for at least a year before the installation and a year after the installation. Corrections are needed to make the before-and-after values comparable as related to annual differences in weather conditions. Also required is an understanding of the effects on conservation of price pressure and education over the period of the program. A simple algorithm based on heating degree days is used to correct for weather differences for that part of the annual fuel use directly related to climate and other factors related to nonclimate-affected fuel use. In the case of boiler heating units with integral instantaneous water heating coils, the summer nonclimate-affected fuel use is not related to heating degree days; therefore, a value for the summer fuel use must be determined or assumed to make corrections using degree days as accurate as possible. 
The evaluation of other simultaneous conservation activities is monitored through the fuel use of a control group of similar houses over the test period where no refits are implied but not guaranteed. BNL can then determine whether only a few winter oil deliveries are necessary to quantify fuel savings, thus reducing the monitoring time considerably by using field-derived fuel delivery data.

\section{A. Preliminary Findings}

1. Conservation due to fuel price pressure contributes to changes in fuel use. An analysis was made of 63 homes to determine the change in annual fuel use from a period in 1977 to 1978 and from 1978 to 1979. This analysis was made to investigate reports by local oil supply companies that there had been a 5 to $10 \%$ reduction in home fuel use, attributed to fuel price pressure and uncertainty regarding fuel availability.

The BNL analysis shows a mean standard annual fuel use vi 1332 gallons with a standard deviation of 255 gallons in 1977-78 and a mean of 1277 gallons with a standard deviation of 227 gallons in 1978-79, a 5.5\% reduction between the two years. There appears to be no material cause for the conservation other than the pressures mentioned above since the 63 homes analyzed are similar in design and construction, with similar boilers and firing rates, in a common location, and with no major weatherization and oil refit options added since they were built in approximately 1965.

2. Following is an analysis summary resulting from field-derived fuel use data from another local oil supply company involving a total of 35 installations of a single brand ' $A$ ' of low speed flame retention head oil burners.

$\frac{\text { Collective fuel use, gal }}{46,307} \frac{\text { Heating degree days (HDD) }}{6032}$

$\begin{array}{lrr}\text { Betore installation } & 46,307 & 6032 \\ \text { After installation } & 41,263 & 6284\end{array}$

Correcting for HDD changes on $80 \%$ of the fuel use (assuming $20 \%$ nonclimateaffected fuel use) shows a savings of $13.8 \%$.

Correcting for HDD changes on $65 \%$ of the fuel use (assuming $35 \%$ nonclimateaffected fuel use) shows a savings of $13.2 \%$

The performance of the low speed retention head burner appears to be as good as that of the high speed design. 


\section{REFIT OPTIONS EVALUATIONS}

The options listed herein are considered SINGLE-CHOICE and are generally of fered as such.

High speed flame retention head burner (3450 rpm motor speed, and is recommended if there is any doubt concerning proper natural draft.)

Low speed flame retention head burner (1.750 rpm motor speed, and is sometimes an installer's choice for reasons related to combustion noise.)

Packaged high efficiency burner-boiler (for forced hot water and steam systems.)

Packaged high efficiency burner-furnace (for forced warm air systems.)

Single function automatic setback thermostat.

Multifunction automatic setback thermostat (this option is desirable for working families.)

Optimized firing rate (reduce firing rate by nozzle replacement.)

Fuel additives - generally added to fuel in storage tank.

Vapor systems - humidified combustion or combustion air passing through water reservoirs.

Rebuilt conventional burners with modified end cones. Tt is generally believed that this option can be labor intensive and require cunsiderable call backs for adjustments.

Manual boiler aquastat reset. This requires knowledge of system and instructions for proper utilization by the homeowner.

\begin{tabular}{|c|c|c|c|c|c|c|c|}
\hline 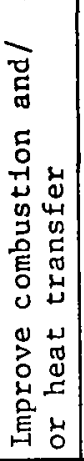 & 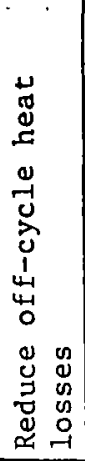 & 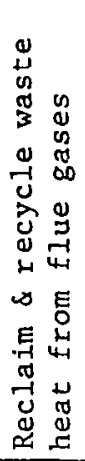 & 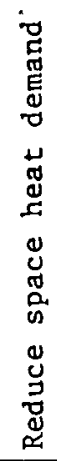 & 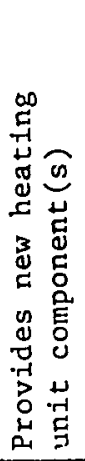 & 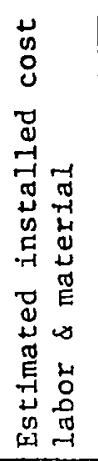 & 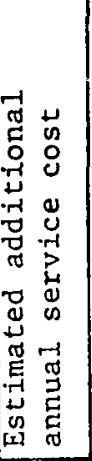 & 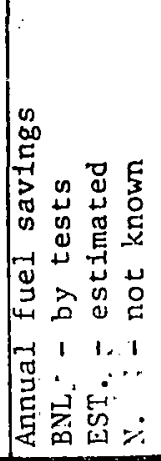 \\
\hline$\checkmark$ & $\checkmark$ & & & $\checkmark$ & $\begin{array}{c}\$ 325 \\
\text { to } \\
450\end{array}$ & 0 & $14 \%$ BNL \\
\hline$\checkmark$ & $\checkmark$ & & & $\checkmark$ & $\begin{array}{c}\$ 325 \\
\text { to } \\
450\end{array}$ & 0 & $14 \%$ BNL \\
\hline$\checkmark$ & $\checkmark$ & & & $\checkmark$ & $\begin{array}{l}\text { up to } \\
\$ 2300\end{array}$ & 0 & $25 \%$ BNL \\
\hline$\checkmark$ & $\checkmark \cdot$ & & & $\checkmark$ & & 0 & $\mathrm{~N}$ \\
\hline & & & $\checkmark$ & & $\begin{array}{c}\$ 50 / \\
\text { zone }\end{array}$ & 0 & $8 \%$ EST. \\
\hline & & & $\checkmark$ & & $\begin{array}{l}\$ 80 . \\
\text { zone }\end{array}$ & 0 & $12 \%$ EST. \\
\hline$\checkmark$ & $\checkmark$ & & & & $\begin{array}{r}\$ 3 \\
\text { to } \\
30\end{array}$ & 0 & $3-5 \%$ BNL \\
\hline$\checkmark$ & & & & & & 0 & $\mathrm{~N}$ \\
\hline$\checkmark$ & & & & & $\$ 300$ & $\$ 30$ & negli. \\
\hline$\gamma$ & $\checkmark$ & & & & & & $\mathrm{N}$ \\
\hline$\checkmark$ & $\checkmark$ & & & & 0 & 0 & $3-5 \%$ BNL \\
\hline
\end{tabular}


Figure 1-a

\section{REFIT OPTIONS EVALUATION}

The options listed herein are considered SINGLE-CHOICE and are generally offered as such.

Optimized fine tune - boiler and furnace application:

- Perform a flue gas analysis using a calibrated analyzer on the existing system after making appropriate adjustments. Record the results.

- Evaluate the condition of the combustion chamber and heat exchanger. Repair or replace as required for safe operation.

- Remove soot and scale from the heat exchanger fireside surfaces and seal all excess air leaks to the combustion chamber.

- Provide the burner with an *end cone to allow for reduced firing rate. Seal all excess air leaks around mounting flange and blast tube.

- Fuel suction line connections should be made airtight.

- Insulate the boiler as required to ninimize jarket losses.

- Operate the burner and adjust (using the flue gas analyzer) in arcordance with the manufacturer's instructions. Necord final results.

- Check for off-cycle after burning and correct the condition immediately using a solenoid shutoff valve if required.

This option includes most of the work necessary to optimize the performance of any oil-fired heating unit.

*Applies to existing retention head burners. 


\begin{tabular}{|c|c|c|c|c|c|c|c|c|}
\hline $\begin{array}{l}\text { REFIT OPTIONS EVALUATIONS } \\
\text { The options listed herein are considered } \\
\text { SINGLE-CHOICE and are generally of fered } \\
\text { as such. }\end{array}$ & 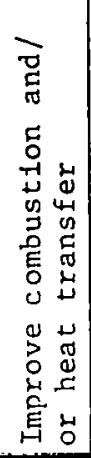 & 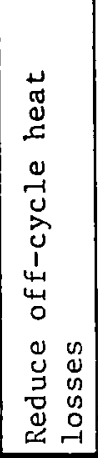 & 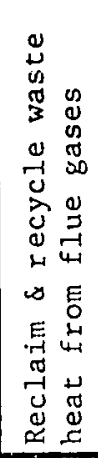 & 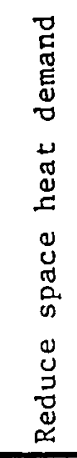 & 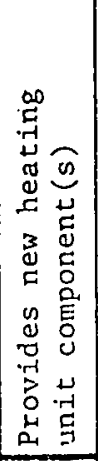 & 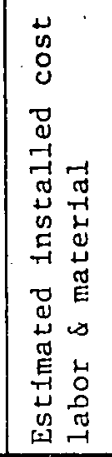 & 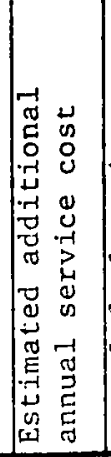 & 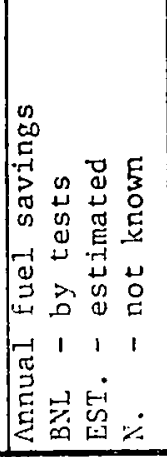 \\
\hline $\begin{array}{l}\text { Automatic aquastat reset control package } \\
\text { (boiler application - hot water system to } \\
\text { reset boiler operating temperature as a } \\
\text { function of outside temperature and is } \\
\text { available with a domestic water heating } \\
\text { programmer for boilers with direct immersion } \\
\text { instantaneous domestic water heaters). }\end{array}$ & $v^{\prime}$ & $j$ & & & & $\$ 275$ & $\operatorname{lup}_{\$ 30}$ to & $10 \%$ EST. \\
\hline $\begin{array}{l}\text { Manual reset of space heat thermostat to } \\
\text { minimize space heat demand. }\end{array}$ & & & & $\checkmark$ & & 0 & 0 & $5 \%$ EST \\
\hline $\begin{array}{l}\text { Economizer - flue gas to water type (typically } \\
\text { builer applicatiun - may cause pressure relief } \\
\text { valve to operate if recirculating pump } \\
\text { fails to operate). }\end{array}$ & $\checkmark$ & & $\checkmark$ & & & $\$ 520$ & $\$ 30$ & $11 \%$ BNL \\
\hline $\begin{array}{l}\text { Economizer - flue gas to air type (typically } \\
\text { furnace application - requires a practical } \\
\text { means to utilize waste heat.) }\end{array}$ & $\checkmark$ & & $\checkmark$ & & & $\begin{array}{l}\$ 150 \\
\text { to } \\
500\end{array}$ & $\$ 30$ & $\mathrm{~N}$ \\
\hline $\begin{array}{l}\text { Motorized vent damper - 3-min timed delay } \\
\text { before damper opens - no bypass in damper. }\end{array}$ & & $\checkmark$ & & & & $\begin{array}{l}\$ 295 \\
\text { to } \\
450 \\
\end{array}$ & $\$ 30$ & $\begin{aligned} & 2 \text { to } \\
& 14 \% \text { BNL } \\
&\end{aligned}$ \\
\hline $\begin{array}{l}\text { Mctorized vent damper - quick closing with } \\
\text { bypass in damper. }\end{array}$ & & 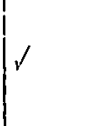 & & & & $\$ 295$ & $\$ 30$ & $\begin{array}{l}2 \text { to } \\
7 \% \text { BNL }\end{array}$ \\
\hline $\begin{array}{l}\text { Turbulators (baffles) (typlcally bulier } \\
\text { application, steel fire-tube type with tur- } \\
\text { bulators installed in the fire tube - may } \\
\text { cause natural draft problems). }\end{array}$ & $\checkmark$ & & & & & $\operatorname{lup}_{\$ 60} t 0$ & 0 & $5 \%$ EST. \\
\hline
\end{tabular}




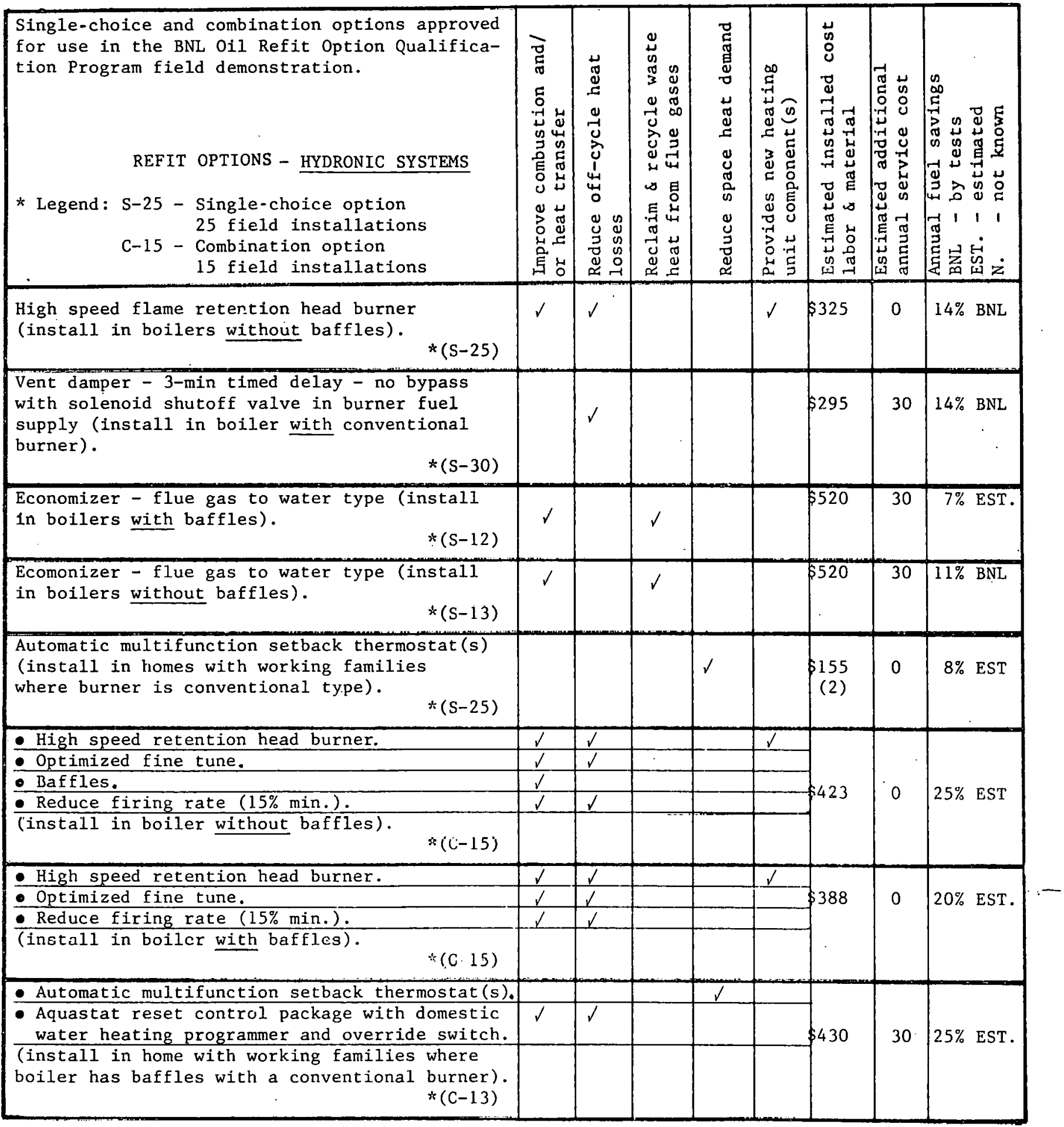


Figure 2-a

Single-choice and combination options approved for use in the BNL Oil Refit Option nualification Program field demonstration.

REFIT OPTIONS - HYDRONIC SYSTEMS

- Automatic multifunction setback thermostat(s)

- Aquastat reset control package with domestic

water heating programmer and override switch. (install in homes with working families where boiler has no baffles with a conventional burner).

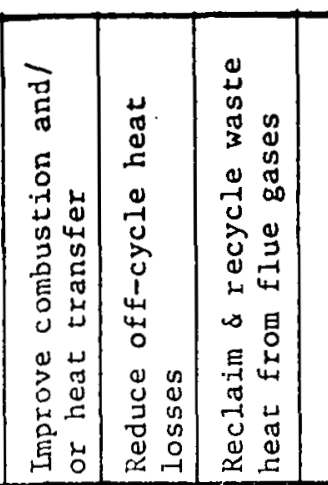

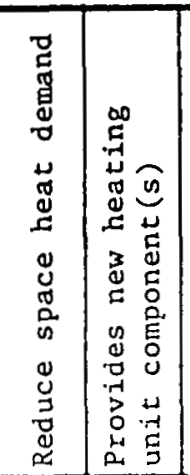

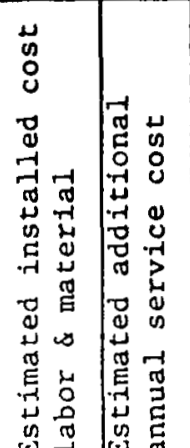

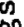

tis

os $\bar{d} 5$

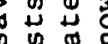

(i)

要品

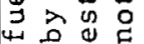

$\rightarrow 11$

불

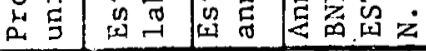

\begin{tabular}{|l|l|l|l|}
\hline$j$ & $\checkmark$ & & \\
\hline
\end{tabular}

- Aquastat reset control package with domestic water heating programmer and override switch. - High speed retention head burner.

- Optimized fine tune.

- Baffles.

- Reduce firing rate (15\% min.)

(install in boiler without baffles).

- Aquastat reset control package with domestic water heating programmer and override switch.

- High speed retention head burner.

- Optimized fine tune.

- Reduce firing rate (15\% min.)

(install in boiler with baffles).

- Vent Damper - 3-inin tilled delay, no bypass with solenoid valve in burner fuel supply.

- High speed retention head burner.

- Optimized fine tune.

- Baffles.

- Reduce firing rate (15\% min.)

(install in boiler with no baffles).

- Vent Damper - 3-min timed delay, no bypass

with solenoid valve in burner fuel supply.

- High speed retention head burner.

- Optimized fine tune.

- Reduce firing rate (15\% Min.)

(install in boiler with baffles).

$\frac{r}{r}$

\begin{tabular}{|c|}
1 \\
\hline
\end{tabular}

$+$

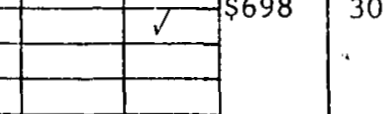

\begin{tabular}{l|l|l|}
\hline & $\gamma$ & $\gamma$ \\
\hline 2) & & \\
\hline
\end{tabular}

$+$

$+$

$+$

$+$

$+1$

...

\begin{tabular}{|c|c|c|}
\hline & \\
\hline & & \\
\hline
\end{tabular}

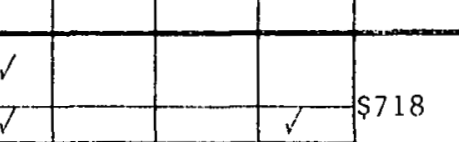


Figure 2-b

\begin{tabular}{|c|c|c|c|c|c|c|c|c|}
\hline 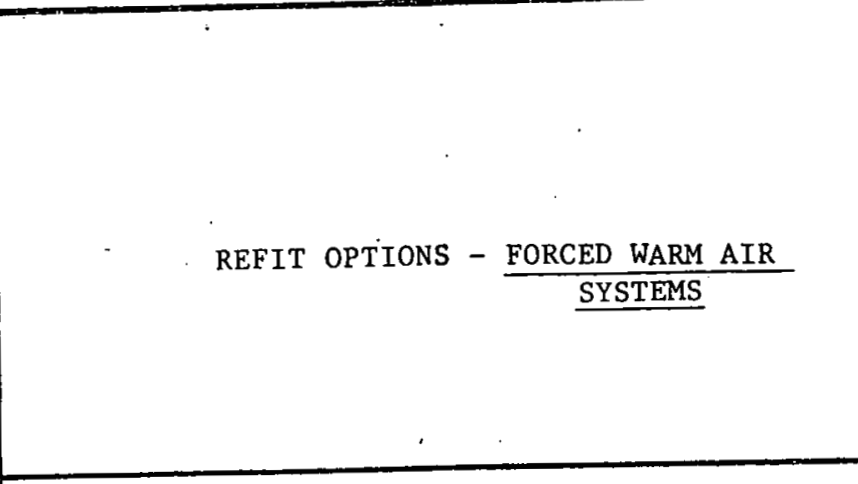 & 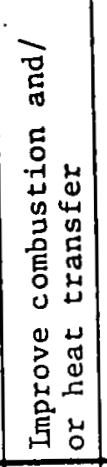 & 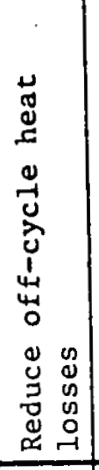 & 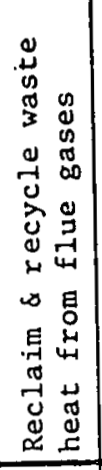 & 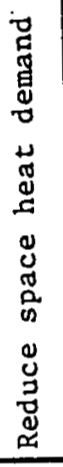 & 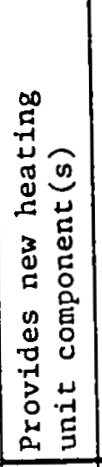 & 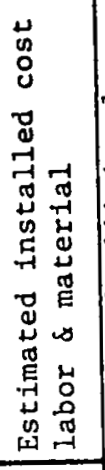 & 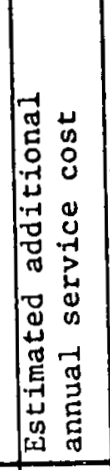 & 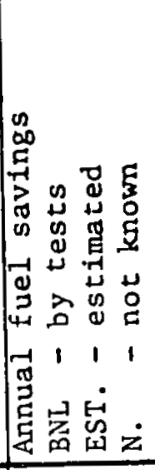 \\
\hline $\begin{array}{l}\text { - High speed retention heat burner with re- } \\
\text { placement combustion chamber liner. }\end{array}$ & $\checkmark$ & $\checkmark$ & & & $\checkmark$ & \multirow[t]{4}{*}{$\$ 500$} & \multirow[t]{4}{*}{0} & \multirow[t]{4}{*}{$\mathrm{N}$} \\
\hline Optimized fine tune. & 7 & $\checkmark$ & & & & & & \\
\hline - Réluce Iiling raile. & $r$ & $\checkmark$ & & & & & & \\
\hline$\star(C-30)$ & & & & & & & & \\
\hline $\begin{array}{l}\text { - Vent Damper - 3-min timed delay, no bypass } \\
\text { with solenoid valve in burner fuel supply. } \\
*(\mathrm{C}-25)\end{array}$ & & $\sqrt{ }$ & & & & $\$ 295$ & 30 & $\mathrm{~N}$ \\
\hline - Optimized fine tune. & $\checkmark$ & $\checkmark$ & & & & \multirow{3}{*}{$\$ 63$} & \multirow{3}{*}{0} & \multirow{3}{*}{$\mathrm{N}$} \\
\hline - Reduce firing rate. & $\checkmark$ & $\checkmark$ & & & & & & \\
\hline Cका & & & & & & & & \\
\hline $\begin{array}{l}\text { - Vent Damper - 3-min timed delay, no bypass } \\
\text { with solenoid valve in burner fuel supply. }\end{array}$ & & $\checkmark$ & & & & \multirow{4}{*}{$\$ 800$} & \multirow{4}{*}{30} & \multirow{4}{*}{$\mathrm{N}$} \\
\hline $\begin{array}{l}\text { - High speed retention head burner with com- } \\
\text { bustion chamber liner. }\end{array}$ & $\checkmark$ & $\checkmark$ & & & $\checkmark$ & & & \\
\hline - Optimized fine tune. & $\sqrt{ }$ & $\checkmark$ & & & & & & \\
\hline - Reduce firing rate. $*(\mathrm{C}-12)$ & $\checkmark$ & i & & & & & & \\
\hline
\end{tabular}

